\title{
Extra-articular tophaceous gout of the Achilles tendon mimicking infection
}

\author{
Benjamin C Chen (10 , ${ }^{1}$ Stephanie J T Chen, ${ }^{2}$ Kyle R Duchman, ${ }^{3}$ Poorani Sekar (ㄷ) ${ }^{4}$
}

${ }^{1}$ Division of Infectious Diseases and Global Public Health, UC San Diego, La Jolla, California, USA

${ }^{2}$ Department of Pathology, University of lowa Hospitals and Clinics, lowa City, lowa, USA ${ }^{3}$ Department of Orthopaedics and Rehabilitation, University of lowa Hospitals and Clinics, lowa City, lowa, USA

${ }^{4}$ Division of Infectious Diseases, University of lowa Hospitals and Clinics, lowa City, lowa, USA

\section{Correspondence to Dr Benjamin C Chen; bencchen89@gmail.com}

Accepted 12 February 2022

Check for updates

C) BMJ Publishing Group Limited 2022. No commercial re-use. See rights and permissions. Published by BMJ.

To cite: Chen $B C$, Chen SJT, Duchman KR, et al. BMJ

Case Rep 2022:15:e247647. doi:10.1136/bcr-2021-

247647

\section{DESCRIPTION}

A 49-year-old man with remote history of traumatic right Achilles tendon rupture from a sports injury treated with primary repair using nonabsorbable suture material and flexor hallucis longus tendon transfer presented with several weeks of pain, warmth and swelling of the right posterior ankle. He underwent two prior irrigation and debridement (I\&D) procedures in the past year at a different institution. In both instances, he was treated with empiric oral antibiotics despite negative bacterial cultures due to concern for infection. His medical history was notable for alcohol use, red meat consumption and history of nephrolithiasis, but no history of gout attacks. On clinical evaluation, the patient was afebrile with erythema, swelling and white discharge noted from a punctate opening along a previous incision over the Achilles tendon. Laboratory evaluation included an erythrocyte sedimentation rate of $36 \mathrm{~mm} /$ hour (normal $0-20 \mathrm{~mm} /$ hour) and a $\mathrm{C}$ reactive protein of $3.0 \mathrm{mg} /$ $\mathrm{dL}$ (normal $<0.5 \mathrm{mg} / \mathrm{dL}$ ). He underwent I\&D of the right Achilles tendon due to concern for surgical site infection. Caseous-appearing material, grossly consistent with tophi, was encountered within the distal Achilles tendon and was sent for bacterial, mycobacterial and fungal cultures, as well as histopathological analysis (figure 1A). He was empirically started on cefazolin postoperatively. Given this tophaceous material noted intraoperatively, dualenergy CT scan of the right ankle was performed postoperatively and demonstrated monosodium urate crystal deposition within the Achilles tendon (figure 1B). Histopathological analysis of the tissue confirmed urate-positive material consistent with gouty tophus (figure 2). Antibiotics were discontinued once bacterial cultures were finalised with

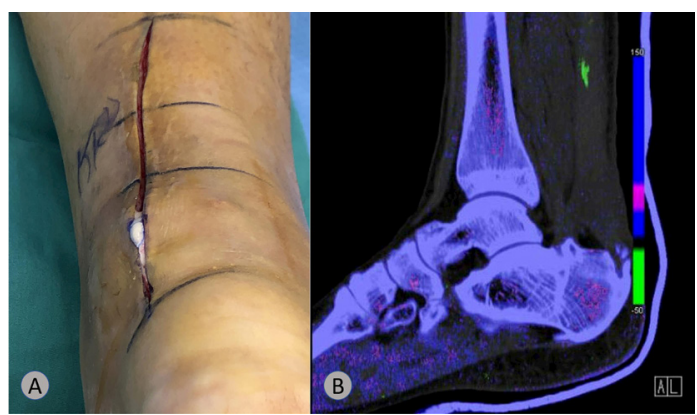

Figure 1 (A) Right Achilles tendon surgical incision with caseous-appearing white material. (B) Dual-energy CT scan of the right ankle with colour coding (green) demonstrating monosodium urate crystal deposition within the Achilles tendon on sagittal view.

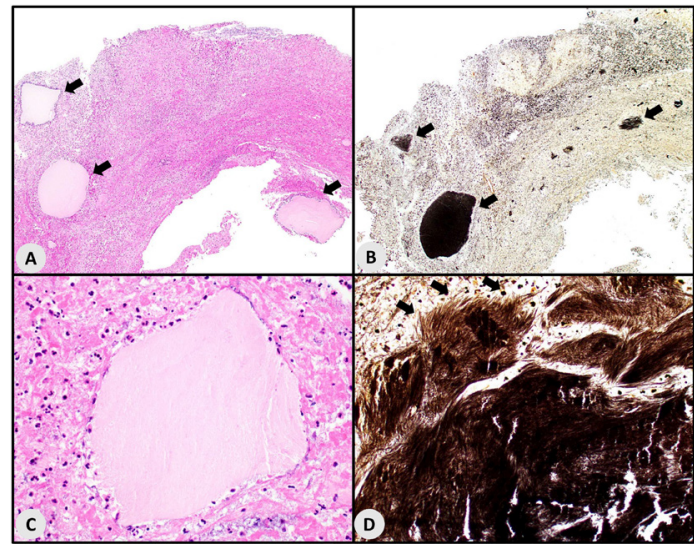

Figure 2 ( $A, B)$ Tophi (arrows) are seen in a background of debris ( $H \& E$ and urate stains, respectively; original magnification $\times 40$ ). (C) Aggregates of amorphous, fluffy, eosinophilic urate crystals float in fibrinous debris with associated neutrophils and histiocytes (H\&E stain; original magnification $\times 400$ ). (D) A corresponding urate stain highlights the slender, long, needle-like nature (arrows) of the urate crystals (urate stain; original magnification $\times 400)$.

no growth. He was treated with non-steroidal antiinflammatory drugs and was referred to a rheumatologist for further treatment. At 6-week follow-up with his orthopaedic surgeon he continued to do well.

Gout is an inflammatory arthritis caused by the deposition of monosodium urate crystals within joints and soft tissue. Symptoms of this disease include acute flares of pain, swelling and erythema of the skin, with eventual development of chronic joint erosions and tophi. ${ }^{1}$ The gold standard for diagnosis remains joint or tophus aspiration with demonstration of monosodium urate crystals on microscopy; however, an aspiration may not always be performed. Multiple imaging modalities, including radiography, ultrasound and CT, can assist with the diagnosis of gout, although only dual-energy CT specifically identifies the chemical composition of uric acid on imaging. ${ }^{2} 3$ Surgery is an uncommon and under-recognised risk factor for the development of gout. Acute gout attacks in the immediate postsurgical period can be attributed to systemic acidosis and microtrauma in distal tissue that trigger uric acid precipitation in predisposed individuals. ${ }^{4}$ A single-institution retrospective study of 302 postoperative patients identified 52 patients with a postsurgical gout attack, occurring at 1-17 days postoperatively; of these, only 7 patients reported this as their first gout attack and the other 
45 patients had a prior diagnosis of gout. ${ }^{5}$ Surgical site gout is exceedingly uncommon years after the index surgery in patients without a history of gout. One other case exists in the literature of a woman with no history of gout who developed tophaceous gout within the Achilles tendon 12 years after a surgical repair. It is postulated that retained suture material acted as a nidus for tophus formation. ${ }^{6}$ A high degree of suspicion is necessary to recognise surgical site gout, especially years after the index surgery. A prompt diagnosis of gout can aid in the judicious use of antimicrobials, as acute gout and surgical site infection share several clinical and laboratory findings. Dual-energy CT is a non-invasive and increasingly available diagnostic modality that is validated in identifying gout in challenging circumstances where the clinical picture is not clear.

\section{Learning points}

- Acute gout can clinically mimic infection and should also be considered when patients present with pain, erythema and swelling at previously injured tendons.

- Isolated, extra-articular gout of the Achilles tendon is rare and a high index of suspicion is needed to make the diagnosis.

- Dual-energy CT is a validated and highly specific imaging modality that can diagnose gout in clinically ambiguous scenarios.
Contributors BCC wrote the first draft of the manuscript. SJTC, KRD and PS critically reviewed and revised the manuscript. All authors read and approved the final paper.

Funding The authors have not declared a specific grant for this research from any funding agency in the public, commercial or not-for-profit sectors.

Competing interests None declared.

Patient consent for publication Obtained.

Provenance and peer review Not commissioned; externally peer reviewed.

Case reports provide a valuable learning resource for the scientific community and can indicate areas of interest for future research. They should not be used in isolation to guide treatment choices or public health policy.

\section{ORCID iDs}

Benjamin C Chen http://orcid.org/0000-0003-4232-2457

Poorani Sekar http://orcid.org/0000-0002-4000-9419

\section{REFERENCES}

1 Dalbeth N, Merriman TR, Stamp LK. Gout. Lancet 2016;388:2039-52.

2 Nicolaou S, Yong-Hing CJ, Galea-Soler S, et al. Dual-energy CT as a potential new diagnostic tool in the management of gout in the acute setting. AJR Am J Roentgenol 2010;194:1072-8.

3 Choi HK, Al-Arfaj AM, Eftekhari A, et al. Dual energy computed tomography in tophaceous gout. Ann Rheum Dis 2009;68:1609-12.

4 Jeong $\mathrm{H}$, Jeon $\mathrm{CH}$. Clinical characteristics and risk factors for gout flare during the postsurgical period. Adv Rheumatol 2019;59:31.

5 Craig MH, Poole GV, Hauser CJ. Postsurgical gout. Am Surg 1995;61:56-9.

6 Giani VC, Gutteling E. Surgical site gout 12 years after an Achilles tendon repair: a case report. JBJS Case Connect 2020;10:e19.00283.

Copyright 2022 BMJ Publishing Group. All rights reserved. For permission to reuse any of this content visit https://www.bmj.com/company/products-services/rights-and-licensing/permissions/

BMJ Case Report Fellows may re-use this article for personal use and teaching without any further permission.

Become a Fellow of BMJ Case Reports today and you can:

- Submit as many cases as you like

- Enjoy fast sympathetic peer review and rapid publication of accepted articles

- Access all the published articles

- Re-use any of the published material for personal use and teaching without further permission

Customer Service

If you have any further queries about your subscription, please contact our customer services team on +44 (0) 2071111105 or via email at support@bmj.com.

Visit casereports.bmj.com for more articles like this and to become a Fellow 